\title{
エストロゲンによる唾液分泌能の変化
}

\author{
老木 浩之 ${ }^{1)} \cdot$ 山本 悦生 ${ }^{2)} \cdot$ 大村 正樹3) $\cdot$ 水上千佳司 ${ }^{4)}$ \\ 小形 哲也 $\left.{ }^{2}\right) \cdot$ 宗田 由紀 ${ }^{3)} \cdot$ 田辺 牧人5) ・ 村田 清高 ${ }^{1)}$

\section{Effect of Estrogen Replacement Therapy on Salivary Flow Dysfunction}

\author{
Hiroyuki Oiki and Kiyotaka Murata \\ (Kinki University) \\ Etsuo Yamamoto and Tetsuya Ogata \\ (Kobe City General Hospital) \\ Masaki Ohmura and Yuki Muneta \\ (Nishi-Kobe Medical Center)
Chikashi Mizukami
(Okazaki City) \\ Makito Tanabe \\ (Kyoto University)
}

\begin{abstract}
Changes in salivary flow rate were evaluated after administration of oral estrogen medication to 4 female patients with menopausal syndrome accompanied by various oral symptoms. Four patients showed symptoms including glossodynia ( 3 cases) and problems with taste ( 1 case). All patients were diagnosed with menopausal syndrome by a gynecologist and were administered oral estrogen medication. Salivary flow rate was evaluated by analysis of the time-activity curve of $99 \mathrm{~m}$ Tc-pertechnetate scintigraphy. Before treatment, 2 patients showed salivary flow hypofunction while the other 2 patients showed normal function. Complaints of each patient were resolved completely a few months after medication was prescribed. The uptake and secretion rates of the parotid glands in all patients increased after medication, but that of the submandibular gland did not change with medication. Thus, there appears to be a difference in the effect of estrogen on salivary flow rates between the parotid and submandibular gland. The results suggested that estrogen replacement therapy could be effective for salivary gland hypofunction.
\end{abstract}

Key words : estrogen replacement therapy, salivary flow rate, glossodynia

5) 京都大学大学院医学研究科感覚運動系病態学講座聴覚・言語病態学領域 
はじめに

舌痛や口内炎など口腔内の諸症状を訴える患者で，高 率に唾夜分泌能の低下がみられることはすでに報告し た ${ }^{11}$. 今回, 我々は, 口腔内の諸症状で当科を受診の後, 更年期障害との診断でェストロゲン製剂の投与を受け， 口腔内症状が著明に改善した症例を経験したので，その 唾液分泌能を中心に報告する。

\section{対象と方法}

対象は, 口腔内の諸症状が数力月以上持続し, 口腔内 に顕著な病的所見を認めない閉経後の症例である. 症例 は表 1 に示寸簡略更年期指数の問診表2)を念頭に置いた 簡単な問診で，「のぼせやすい」や「汗をかきやすい」 など更年期障害が疑われた症例で，産婦人科受診に同意 し，当科から診療依頼した 4 例である. 4 例は，いずれ も産婦人科受診で更年期障害の診断を受け，エストロゲ ン製剤の内服治療を開始された。当科では, 口腔内症 状の経過観察とテクネシウム， ${ }^{99 m}$ Tc-pertechnetate $\left({ }^{99} \mathrm{TcO}_{4}\right.$-) を用いたシンチグラフィー検査(以下, $\mathrm{Tc}$ シンチと略す)による唾液分泌能の評価を行った，Tc シンチでは, 耳下腺, 顩下腺の左右 4 腺を関心領域とし て, 集積カウント数の時間経過を動態曲線として描出し, 安静時の機能，唾液分泌刺激時の機能に分けて評価した. 安静時にはピーク時のカウント数を投与総カウント数で 除して摂取率を求め, 刺激時には刺激後の最低值のカウ ント数をピーク時から減じてから投与総カウント数で除 し，分泌率として数值化した．検査方法の詳細は別に報 告する ${ }^{3)}$.

\section{結 果}

症例の詳細を表 2 に示す. 年齢は51〜 54歳で, 閉経後 4 カ月から 2 年を経過していた. 主訴は， 3 例が舌のピ リピリした痛み，1例が口の中が苦い，であった。治療 前後の摂取率と分泌率を表 3 に示す．正常值は，十分に 満足できるものではないが，すでに報告したと拈り，唾 液腺腫瘍症例の正常唾液腺から 1 標準偏差以内として算

表 1 簡略更年期指数 ${ }^{2)}$

\begin{tabular}{|c|c|c|c|c|}
\hline \multirow[t]{2}{*}{ 症状 } & \multicolumn{4}{|c|}{ 症状の程度（点数） } \\
\hline & 強 & 中 & 弱 & 無 \\
\hline 1. 顔がほてる & 10 & 6 & 3 & 0 \\
\hline 2. 汗をかきやすい & 10 & 6 & 3 & 0 \\
\hline 3. 腰や手足が冷えやすい & 14 & 9 & 5 & 0 \\
\hline 4. 息切れ、動悸がする & 12 & 8 & 4 & 0 \\
\hline 5. 寝つきが悪い、または眠りが浅い & 14 & 9 & 5 & 0 \\
\hline 6. 怒りやすく、すぐいらいらする & 12 & 8 & 4 & 0 \\
\hline 7.くよくよしたり、豪滞になることがある & 7 & 5 & 3 & 0 \\
\hline 8. 頭痛、めまい、吐き気がよくある & 7 & 5 & 3 & 0 \\
\hline 9. 疲れやすい & 7 & 4 & 2 & 0 \\
\hline 10．肩こり、腰痛、手足の痛みがある & 7 & 5 & 3 & 0 \\
\hline
\end{tabular}

$0 \sim 25$ 点 問題なし

$26 \sim 50$ 点 食事、運動に気をつけ、無理しないように

$51 \sim 65$ 点 更年期一閉経外来で生活指算カウンセリング、薬物療法を受けたほうがよい

$66 \sim 80$ 点 長期 (半年以上) の治亦が必要

$81 \sim 100$ 点 各科の精密検查を受け、更年期障害のみである場合は、更年期一閉経

外来で長期の治療が必要

表 2 対象症例

\begin{tabular}{cllccc}
\hline \hline 症例 & 年橉 & 主訴 & 口内乾燥感 & 閉経後(月) 病悩期間(月) \\
\hline 1 & 54 & 舌痛 & 有 & 4 & 4 \\
2 & 53 & 口内の苦み & 無 & 24 & 5 \\
3 & 53 & 舌痛 & 有 & 12 & 2 \\
4 & 51 & 舌痛 & 無 & 19 & 3
\end{tabular}


表 3 治療前後の唾液分泌能

\begin{tabular}{|c|c|c|c|c|c|c|c|c|c|c|}
\hline \multirow{3}{*}{$\begin{array}{l}\text { 症 } \\
\text { 例 }\end{array}$} & \multirow{3}{*}{$\begin{array}{l}\text { 治 } \\
\text { 療 }\end{array}$} & \multirow{3}{*}{$\begin{array}{l}\text { 期 } \\
\text { 間 } \\
\text { 合 }\end{array}$} & \multicolumn{4}{|c|}{ 摂取率 } & \multicolumn{4}{|c|}{ 分泌率 } \\
\hline & & & \multicolumn{2}{|c|}{ 耳下腺 } & \multicolumn{2}{|c|}{ 顎下腺 } & \multicolumn{2}{|c|}{ 耳下腺 } & \multicolumn{2}{|c|}{ 顎下腺 } \\
\hline & & & 右 & 左 & 右 & 左 & 右 & 左 & 右 & 左 \\
\hline \multirow{2}{*}{1} & 前 & \multirow{2}{*}{4} & 0.27 & 0.53 & 0.13 & 0.18 & 0.19 & 0.38 & 0.04 & 0.05 \\
\hline & 後。 & & 0.45 & 0.65 & 0.11 & 0.16 & 0.30 & 0.45 & 0.03 & 0.05 \\
\hline \multirow{2}{*}{2} & 前 & \multirow{2}{*}{4} & 0.24 & 0.33 & 0.39 & 0.28 & 0.04 & 0.22 & 0.18 & 0.15 \\
\hline & 後。 & & 0.31 & 0.26 & 0.32 & 0.30 & 0.17 & 0.15 & 0.15 & 0.07 \\
\hline \multirow[t]{2}{*}{3} & 前 & \multirow{2}{*}{2} & 0.32 & 0.62 & 0.39 & 0.52 & 0.19 & 0.39 & 0.16 & 0.26 \\
\hline & 後 & & 0.38 & 0.63 & 0.33 & 0.42 & 0.26 & 0.40 & 0.15 & 0.18 \\
\hline \multirow[t]{2}{*}{4} & 前 & & 0.44 & 0.52 & 0.50 & 0.57 & 0.33 & 0.30 & 0.30 & 0.35 \\
\hline & 正: & & $\geqq 0$ & & $\geqq$ & & 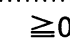 & & & .13 \\
\hline
\end{tabular}

定したものを用いた1). 以下，各症例毎の唾液分泌能と 治療経過を示寸。

(症例 1 )

54歳，主訴は舌尖部のピリピリした痛みで，本症例で は閉経期と口腔内症状の自覚時期とが一致していた．治 療前, 頸下腺機能が摄取率, 分泌率とも低下し, 右耳下 腺摂取率も低下していた．参考として動態曲線を図 1 亿 示す. エストロゲンの投与後は約 4 週間で症状が消失し， 4 力月後の再検查では右耳下腺機能が摂取率, 分泌率と も改善された (表 2 )．治療前から正常範囲内であった左 耳下腺機能も充進した。㴿下腺機能の変化はほとんど認 められなかった.
(症例 2)

53歳, 口内の苦みが主訴である. 右耳下腺の摂取率, 分泌率, 左䋶下腺の摂取率低下が認められた. 治療は当 初, 結合型エストロゲン $2.5 \mathrm{mg}$ の投与を受けていたが, 改善傾向がないため 2 カ月後に $5 \mathrm{mg}$ に増量された。さ らに，その 2 カ月後から徐々に自覚症状が改善しはじめ た．その頃の動態曲線を図 2 に示す．右耳下腺は拱取率， 分泌率とも改善しているが，それ以外の腺では概ね，わ ずかだが，むしろ低下する傾向にあった。な执，治療開 始後 6 力月で自覚症状は完全に消失した.

(症例 3 )

53歳, 舌痛を主訴として来院した. 治療前, 摂取率, 分泌率は全て正常範囲内にあったが，耳下腺ではェスト ロゲンの投与により充進し, 顝下腺では低下寸る傾向が 認められた (図 3$)$. 本症例は治療後 1 カ月で自覚症状が 消失した。

(症例 4 )

51歳で，同じく舌痛が主訴であった．治療前には症例 3 と同様, 摄取率, 分泌率は全て正常範囲内にあった. 本症例は，エストロゲン治療 6 週間で症状は消失したが， その後は来院せず，Tc シンチの再検はできなかった.

今回のエストロゲン投与による摂取率の変化を図 4 に まとめた. 耳下腺, 顎下腺とも 1 側を除いて, 耳下腺で は分泌が増加し，顎下腺では逆に低下した。

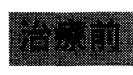

安静時

刺激時
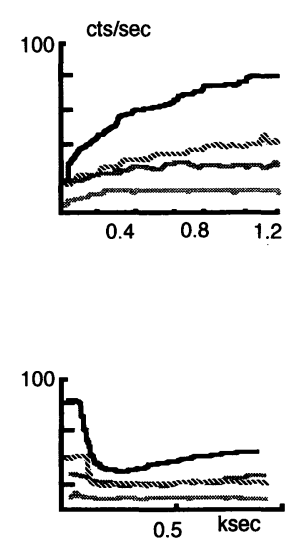
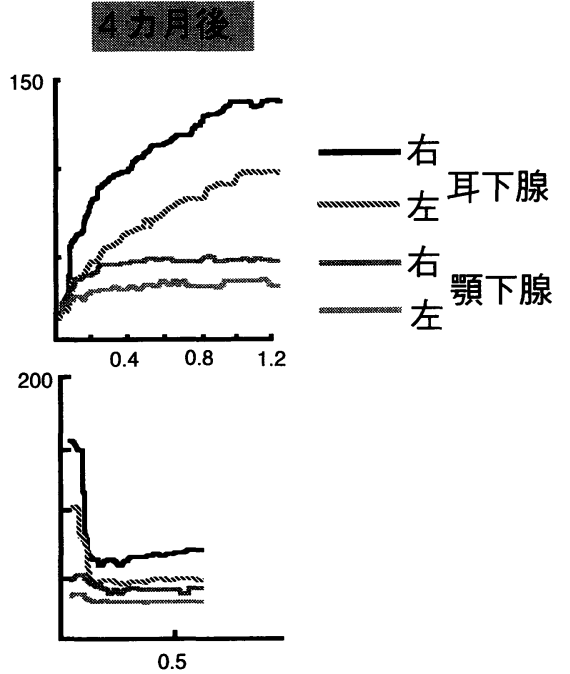

図 1 症例 1 の Tc シンチ動態曲線 


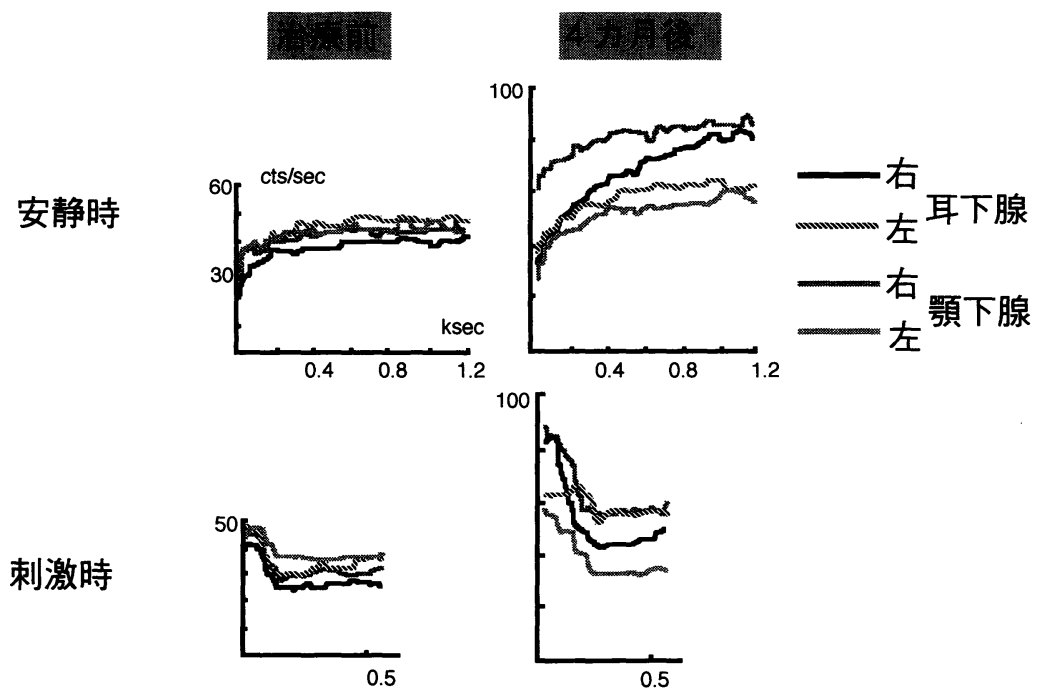

図 2 症例 2 の Tc シンチ動態曲線



図 3 症例 3 の Tc シンチ動態曲線

考察

唾液分泌と女性ホルモンとの関連性は古くから指摘さ れ, 月経周期, 妊娠による唾液分泌量の変動4) 6) が知ら れており，さらに女性の唾液分泌能の年齛変化の検討か らも唾液分泌に対する女性ホルモンの関与が示唆されて (る1)7) 9).

また，基礎的検討においても，ヒトやラットで唾液腺 内にエストロゲン・リセプターなどの性ホルモン受容体 が存在し10)11)，マウスでは顎下腺内にアンドロゲン・リ
セプターが認められて打り12)，唾液腺が各種性ホルモン の標的臓器であることは間違いない，今回の結果は，エ ストロゲンが耳下腺の唾液分泌を亢進し，顎下腺の唾液 分泌には影響しないという作用を持つ可能性を示唆した ものと考えられる。このことは，ヒト唾液腺で男性より 女女性にエストロゲン・リセプターが多く, また男性症 例だけだが，㴿下腺よりも耳下腺に多く分布しているら しいといら過去の基礎的報告13) と関連のある結果とい えるかもしれない。また，ヒトとは逆に，ラットではエ 


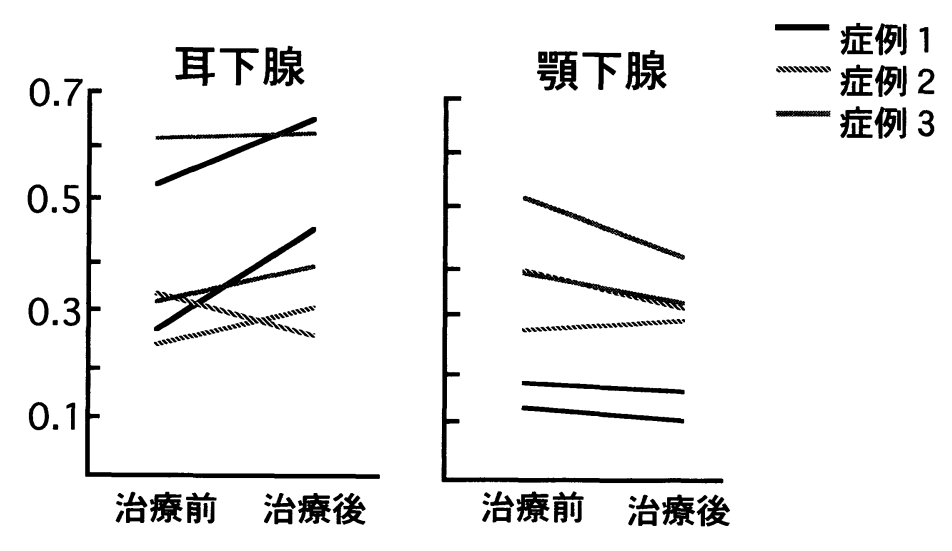

図4 エストロゲンによる摂取率の変化

ストロゲン・リセプターの分布密度は耳下腺よりも顎下 腺で有意に高いこと10)が示されて拈り，種差なども検 討する必要があろらが，いずれにしても耳下腺，顎下腺 でその分布密度が異なる点が興味深い事実といえる。ま た臨床的にも最近の我々の研究9) で，加龄により耳下腺 機能が低下し, 顎下腺機能の変化が認められない傾向に あったという事実にも, 今回の結果は適合しているもの と考えられる. しかし, 実際, 性ホルモンが唾液腺上の リセプターに結合したときの働きについて報告している ものは少なく，わずかにアンドロゲンの投与でマウス䋶 下腺顆粒導管細胞の増殖が報告されている14) が, 詳細 はいまだ不明である。

今回の結果では, エストロゲンの投与により, 耳下腺 分泌機能が改善もしくは立進し，それとは逆に䫇下腺機 能はわずかに低下する傾向が認められた。しかしながら， 前述のよらに，唾液腺にはエストロゲン・リセプターが 存在することは知られているものの, エストロゲンが喠 液腺に直接作用したかどらかは不明である。また，耳下 腺機能が亢進したことによって口腔内症状が改善したと 結論づけるのは早計である。つまり，今回の対象症例の 主訴は 4 例中 3 例が舌痛であり, 舌痛症の本態がいまだ 確立されていないため, 耳下腺唾液分泌元進のために症 状が消失したかどらかは不明である．舌痛症の原因とし

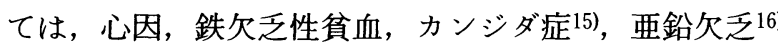
などが列挙される一方，我々の過去の検討では舌痛を訴 えた 9 例中 7 例に吽液分泌低下が認められ, 唾液分泌低 下が舌痛症の有力な原因の 1 つとなっている可能性があ ることを指摘した1). したがって，今回の結果も舌痛症
の原因が唾液分泌低下にあることを示唆した結果である 可能性は十分に考えられる。今後は対象症例の増加を待 って, 種々の問題点について検討したい.

口内乾燥症の治療薬としては, ビソルボン®(塩酸ブ ロムヘキシン)，セファランチン®，パロチン®，人工唾 液 $\left(\right.$ サリベート $\left.{ }^{\circledR}\right){ }^{17)}$ ，チスタニン® $(\mathrm{L} \text {-システイソ })^{18)}$, 白虎加人参湯 ${ }^{19)}$ ，麦門冬湯20)21)，フェルビテン® (Anethol Trithion, FEM-102)22) などが報告されている が，以上の薬剤は我々の経験でも必ずしも満足な効果が 得られているとはいいがたい。ささ，今回検討したエス トロゲンの内服治療は, 唾液分泌々のものを改善させる 可能性があり, 今後, 口内乾燥症の治療として新たに考 慮する価値があるものと考えられる。しかし，近年，更 年期障害の治療法として, 産婦人科領域でも世界的に普 及しつつある，エストロゲンなどの少量長期内服療法 (ホルモン補充療法;HRT (hormone replacement therapy))は，諡った投与法で乳癌，子宮癌の発生率を 上昇させることが知られて拈り223)，耳鼻科医による安 易な投与は危険であり，産婦人科医による診断と治療が 不可欠であるものと思われる.

$$
\text { まとめ }
$$

1. 口腔内症状のある, 閉経後の 4 例でエストロゲン 治療前後の唾液分泌能を測定した。

2. 自覚症状は 4 例とも消失し，唾液腺機能検査では， 耳下腺機能が亢進, 顎下腺機能がやや低下寸る傾向が認 められた。

3. 口内乾燥症の治療として，エストロゲンが有効な 
可能性が示唆された.

本論文の要旨は, 第 56 回耳鼻咽喉科臨床学会 (平成 6 年 7 月 16〜17日, 鹿児島)においてロ演した.

\section{参考文献}

1 ）老木浩之, 山本悦生, 大村正樹, 他 : 口腔内諸症状之唾液 分泌能. 口咽科 $6: 151 \sim 157,1994$.

2 ) 小山嵩夫 : 更年期-閉経外来 一更年期から老年期の婦人の 健康管理について一. 日本医師会雑誌 $109: 259 \sim 264,1993$.

3 ）老木浩之, 山本悦生, 大村正樹, 他 : Tc シンチによる唾 液分泌機能検査の検討. 耳鼻臨床 $88: 1319 \sim 1328,1995$.

4) Kullander L and Sonesson B: Studies on saliva in menstruating, pregnant and post-menopausal women. Acta Endocrinologica $48: 329 \sim 336,1965$.

5 ) Hugoson A : Salivary secretion in pregnancy; a longitudinal study of flow rate, total protein, sodium, potassium and calcium concentration in parotid saliva from pregnant women. Acta Odontol Scand $30: 49 \sim 66,1972$.

6 ) Wardrop RW, Hailes J, Burger H, et al : Oral discomfort at menopause. Oral Surg Oral Med Oral Pathol $67: 535 \sim$ 540, 1989.

7 ) 今野昭義, 伊藤永子, 岡本美孝 : 加齢による唾夜腺の変化 と口内乾燥症. 日耳鼻 $91: 1837 \sim 1846,1988$.

8 ）池田 稔, 濱田敬永, 田中正美, 他 : 口腔の異常. 耳喉頭 頸 $63: 209 \sim 216,1991$.

9 ）老木浩之, 山本悦生, 村田清高 : 加齢による唾液分泌能の 変化. 口咽科 $7: 139 \sim 144,1995$.

10) Campbell PS, Ben-Aryeh $H$ and Swanson KA : Differential distribution of an estrogen receptor in the submandibular and parotid salivary glands of female rats. Endocr Res $16: 333 \sim 345,1990$.

11）隈上秀伯, 中島成人：耳鼻咽喉科疾患と性ホルモン. 耳鼻
臨床 $85 ： 1183 \sim 1194,1992$.

12）竹村秀一, 樽井まゆみ, 小当真理, 他 : ラット靧下腺中の Androgen Receptor に関する研究. 神奈川歯学 $17: 525$ 535, 1983.

13) Dimery IW, Jones LA, Verjan RP, et al : Estrogen receptors in normal salivary gland and salivary carcinoma. Arch Otolaryngol Head Neck Surg 113 : 1082 1085, 1987.

14）伊東眞人：マウス顎下腺におけるホルモン反応性細胞増殖 の検索. 日耳鼻 $90: 590 \sim 597,1987$.

15）大島 自, 市原三千子, 岡崎則子, 他 : 舌疼痛执よび味覚 障害を訴えた患者に対する臨床的, 生理学的検討. 心身歯 $5: 48 \sim 56,1990$.

16）田中正美, 冨田 寛: 舌痛症. 日本耳鼻咽喉科学会専門医 通信 $41:$ 16 17, 1994.

17）佐藤雅志, 賀来 亨 : 口内乾燥症の診断と治療. JOHNS $5: 971 \sim 980,1989$.

18）又賀 泉, 土持 眞, 土川幸三, 他: 高齢者における口腔 乾燥症の検討 (その 1). 老年歯学 3: 56〜 67, 1989.

19）山内康平, 三木知博 : 高㱓者の乾燥症状に対する白虎加人 参湯の治療効果. 和漢医薬学会誌 $6: 274 \sim 275,1989$.

20）山田 隆, 後藤 畺: ツムラ麦門冬湯の乾燥症候群に対す る長期投与成績. 漢方医学 $13: 183 \sim 187,1989$.

21）山際幹和：口渴, 口乾に対する漢方製剤の効果. 口咽科 2 : 61〜65, 1990.

22）鵜飼洋司郎, 竹下恵子, 樋口智子, 他 : Anethole Trithione の唾液分泌促進作用について. 薬理と治療 18 : 1051 1055, 1990.

23）小山嵩夫：ホルモン補充療法. ドクターサロン 38 : 463〜 469, 1994.

/原稿受付 : 平成 7 年 5 月 25 日 原稿採択 : 平成 7 年 7 月 12 日 別刷請求先 : 老木浩之 干589 大阪狭山市大野東377-2 近畿大学医学部耳鼻咽喉科学教室 